\title{
ASSESSMENT AND MAPPING OF SURFACE WATER QUALITY INDEX FOR IRRIGATION PURPOSE: CASE STUDY NORTHWEST OF NILE DELTA, EGYPT
}

\author{
Radwa A. El Behairy, A. A. El Baroudy, M. M. Ibrahim and M. S Shokr \\ Soil and water department, Faculty of Agriculture, Tanta university, Egypt \\ ${ }^{*}$ Correspondence: Mohamed S Shokr \\ Emails: Mohamed shokr@agr.tanta.edu.eg \\ m.s012@yahoo.com
}

Received: June. 2, 2021

Accepted: June. 8, 2021

\begin{abstract}
Shortness and contamination of water become one of the most hazards facing Egypt nowadays. The irrigation water quality index (IWQI) was calculated in this research to classify surface water of some irrigation canals northwest of Nile delta, Egypt. For this purpose, 14 sites distributed within study area were selected to take water samples during October 2019. ArcGIS (10.4.1) spatial Analyst extension was used to produce high accuracy maps. The IWQI spatial distribution within the study area shows that, samples fell into four classes, low restriction (LR) moderate restriction (MR) High restriction (HR) severe restriction (SR) with an area 178,138, 92 and $249, \mathrm{Km}^{2}$ respectively. The area of SR water quality would be sited in the northeast and southwest in resultant of increase the EC, SAR, $\left(\mathrm{Na}^{+}\right)$and $\left(\mathrm{Cl}^{-}\right)$ions in this direction. The descending order of water restriction use in the study area is SR> LR> MR > HR. Thus, most of surface water in the study area (73\%) may avoided its use for irrigation under ordinary conditions. It should be used with high permeability soil and with plants that appear high resistance for salinity with special salinity control practices.
\end{abstract}

Key words: Irrigation Water Quality Index; High accuracy maps; GIS; Nile Delta; Egypt

\section{INTRODUCTION}

A lot of major problems facing humanity in the $21^{\text {st }}$ century associated with quantity and/or water quality issues (UNESCO, 2009). These problems will be worse in the future due to climate change which will cause higher water temperatures, melting glaciers, and an intensification of the water cycle (Huntington, 2006). Most of the drainage canals are likely polluted by discharges of untreated domestic and industrial wastewater while approximately $55 \%$ of agricultural drainage water (ADW) is officially reused for irrigation purposes (Hafez,2005). In Egypt, more than 17 billion cubic meters (BCM) of agricultural water per year represents a potential backbone for non-conventional water resources in this country (Assar et al., 2018). Egyptians consider drainage water as a resource for irrigation in the face of water shortage thus, it makes the quality of the water in the canals become progressively worse (Khater et al., 2014). The major consumer of water in the world is agriculture that uses more than $63 \%$ of the World's available freshwater resources for irrigation (Aliyu et al. 2017). In Egypt, the agriculture sector consumes about $80-85 \%$ of all available water resources (Negm et al., 2019). The quality of water is defined as the normal, physical, and compound condition of the water in addition any adjustment that may have been initiated by human impacts (Venkateswaran et al. 2011; Jafar et al. 2013; Khan et al. 2012 and Salahat et al. 2014). Assessment of Irrigation Water Quality index(IWQI) is very essential to avoid or, at least, to decrease impacts on agriculture (Mohammed, 
2011). Also, IWQI is one of the most vital factors which effect on human health and other living organisms (Bhuyan et al. 2018). It defines irrigation water quality by single value, thus avoiding water quality evaluations involving complex data intervals (Ghazaryan and Chen, 2016) and is based on the recommended limitations for continues water usage for all soil types (Stoner, 1978). Although spatial and temporal variations in water quality, which are often difficult to interpret, a monitoring program of surface waters quality can provide a representative and reliable estimation (Noori et al., 2012). Using of Geographic information system (GIS) and WQI methods could provide a monitoring report data to decision makes to understand the quality of surface water and to reach to the optimum use in the future as well (Rasul and Waqed, 2013). Many researches used irrigation water quality index (IWQI) as a management tool to measure water quality (Jerome and Pius 2010; Rokbani et al. 2011). The main aim of this research is to provide spatial distribution maps for irrigation water quality index (IWQI) parameters to help decision makers to identify the water quality status of study area and reach to optimum use of water resources. Even though many researchers were worked on determining IWQI, very few researchers were mapped it in their studies area. As for as our knowledge, no spatial distribution maps for the IWQI has been carried out for the study area, in Northwest of Nile delta, Egypt.

\section{MATERIALS AND METHODS}

\section{Description of study area}

The study area is situated in the Northwest of the Nile Delta, and extended between longitudes $29^{\circ} 51^{\prime} 30^{\prime} \& 30^{\circ} 31^{\prime}$ $08^{\prime \prime} \mathrm{E}$, and latitudes $30^{\circ} 59^{\prime} 15^{\prime \prime} \& 30^{\circ} 26^{\prime}$ $45^{\prime \prime} \mathrm{N}$, with total area $767 \mathrm{~km}^{2}(\mathrm{Fig}, 1)$. The area is characterized by Mediterranean Sea climate. The maximum temperature is relatively high in dry season as it recorded $30.0^{\circ} \mathrm{C}$, where the average minimum temperature was $13.0^{\circ} \mathrm{C}$ in January. Little rain occurred in winter from November to February as in Egypt, rainfall is light and shower while, the maximum rainfall was in January $\mathbf{( 5 9 . 2 0}$ $\mathrm{mm})$. The lowest value of evaporation was recorded in January and December due to low temperature, whereas the highest value observed in June and September which temperature is comparatively high. The annual average of evaporation is $4.25 \mathrm{~mm} /$ day. The lowest proportion of relative humidity was observed in April (51\%) while the highest was in December with 58.4\% (Climatological Normal for Egypt, 2011). The soil temperature regime is "Thermic" and the soil moisture regime could be defined as "Torric". The studied area is formed by Holocene deposits (Said, 1993). The irrigation system is mostly surface irrigation, in which water is pumped from irrigation canals using furrow and basin irrigation.

\section{Collecting samples}

After a detailed survey, 14 water samples were collected from all irrigation canals in the study area on October 2019 (Fig, 2.) using plastic containers (each with a capacity of 1 liter). Before using of plastic containers, they were rinsed thoroughly with sampling water and sealed, then kept in ice-boxes and transferred to laboratory for analysis of the soil reaction $(\mathrm{pH})$, Electrical Conductivity (EC), Calcium (Ca), Magnesium (Mg), Sodium ( $\mathrm{Na})$, Potassium (K), Chloride (Cl), Bicarbonates $\left(\mathrm{HCO}_{3}\right)$ and Sulfate $\left(\mathrm{SO}_{4}\right)$. Sodium adsorption ratio (SAR) and irrigation water quality index (IWQI) were calculated for surface water quality evaluation of in the study area. The analysis was carried out according to APHA (2012). Descriptive statistics including minimum, maximum, average and standard deviation were calculated. 


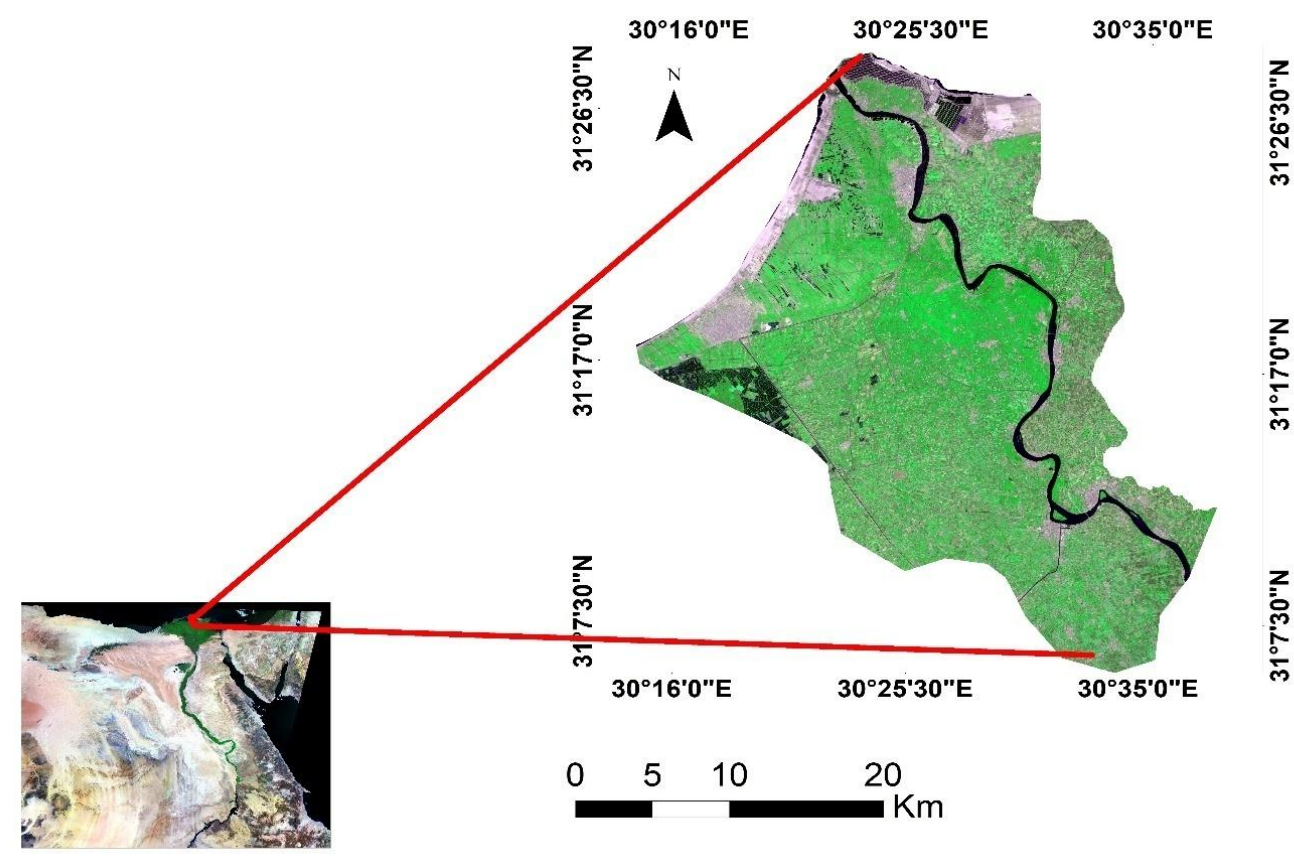

Fig (1): Location of the study area, relative to Egypt Map.

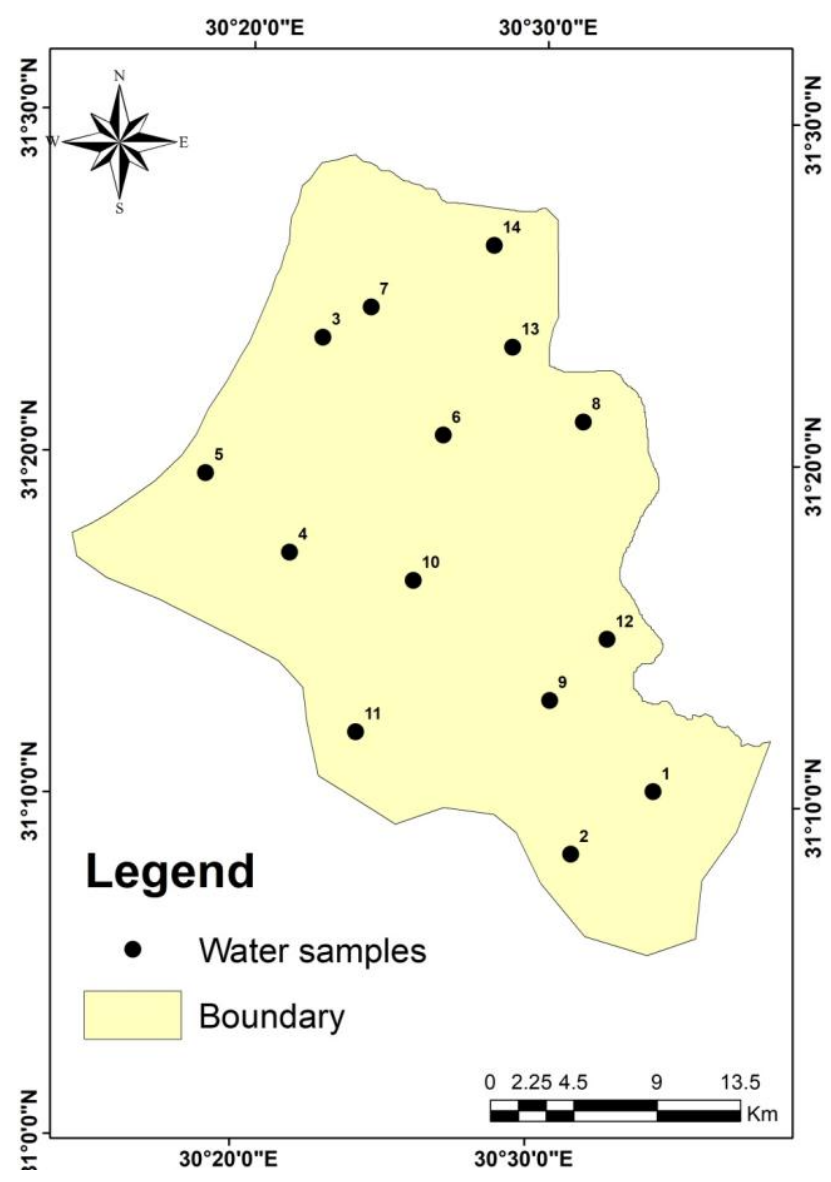

Fig (2): Distribution of samples sites. 
Radwa A. El Behairy, et al.,

\section{Assessment of water quality}

\subsection{Guidelines for water quality}

Many researches have been proposed a lot of water quality classification schemes. Permissible limits for irrigation which recommend by Scofield (1936). In addition, water quality standards for agriculture use by FAO (1985) were used as a guide to show water quality of study area (Tables 1 and 2).

\subsection{Irrigation Water Quality Index (IWQI) modeling:}

The developed irrigation water quality index by Meireles et al. (2010) was used to calculate IWQI of study area, which reflects soil salinity, soditiy hazards and water toxicity to plants. The parameters of this specified model are $\mathrm{EC}, \mathrm{Na}^{+}, \mathrm{Cl}^{-}$, SAR and $\mathrm{HCO}_{3}^{-}$. The process of quality evaluation is based on WQI (Meireles et al. 2010). This model is depending on two steps, first one is to determine the parameters which more related to the irrigation use and the second step are establish of a quality measurement values (qi) and aggregation weights (wi). Irrigation water quality parameters recommended by the California University Committee of Consultant (UCCC) and by the criteria recognized by Ayers and Westcot (1999) were used to determine value of each parameter (Table, 3). The higher the value represent better water quality.

Table (1): Allowable limits for irrigation water classes (Scofield, 1936).

\begin{tabular}{|c|c|c|c|c|c|c|}
\hline \multirow{2}{*}{\multicolumn{2}{|c|}{ Class of water }} & \multirow{2}{*}{$\frac{E C}{\left(\mu \mathrm{mhos} \mathrm{cm}^{-1}\right)}$} & \multicolumn{2}{|c|}{ Gravimetric Sodium } & Chloride & Sulfate \\
\hline & & & $\left(\mathrm{mg} \mathrm{L}^{-1}\right)$ & $(\%)$ & \multicolumn{2}{|c|}{$\left(\mathrm{meq} \mathrm{L}^{-1}\right)$} \\
\hline $\begin{array}{l}\text { Class } 1 \\
\text { Class } 2 \\
\text { Class } 3 \\
\text { Class } 4 \\
\text { Class } 5\end{array}$ & $\begin{array}{l}\text { Excellent } \\
\text { Good } \\
\text { Permissible } \\
\text { Doubtful } \\
\text { Unsuitable }\end{array}$ & $\begin{array}{c}<250 \\
250-750 \\
750-2000 \\
2000-3000 \\
>3000\end{array}$ & $\begin{array}{c}<175 \\
175-525 \\
525-1400 \\
1400-2100 \\
>2100\end{array}$ & $\begin{array}{c}<20 \\
20-40 \\
40-60 \\
60-80 \\
>80 \\
\end{array}$ & $\begin{array}{c}<4 \\
4-7 \\
7-12 \\
12-20 \\
>20 \\
\end{array}$ & $\begin{array}{c}<4 \\
4-7 \\
7-12 \\
12-20 \\
>20\end{array}$ \\
\hline
\end{tabular}

Table (2): Guidelines of water quality Interpretation for Irrigation (FAO,1985).

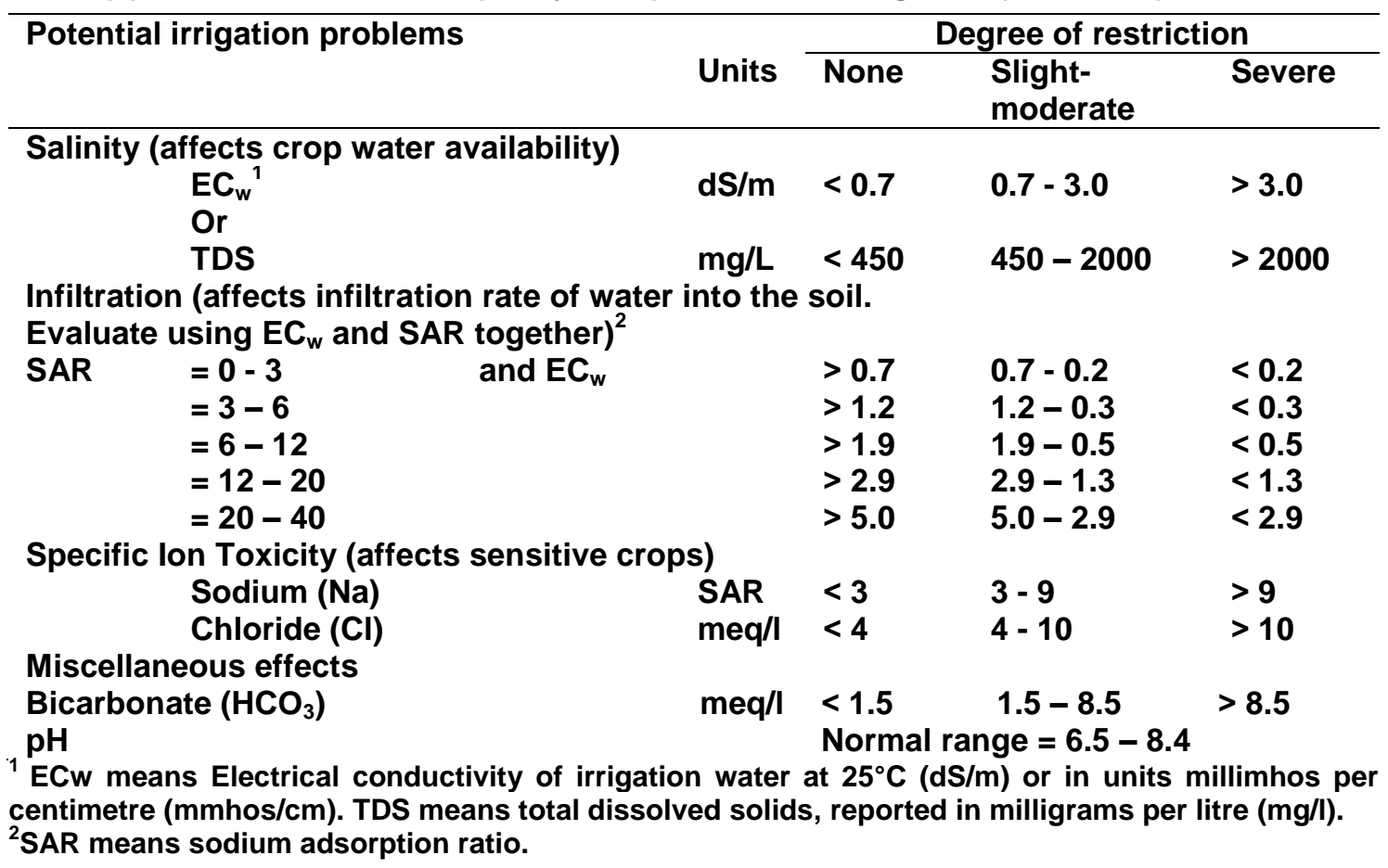


Table (3): Parameter Limiting Values for Quality Measurement (qi) Calculation (Ayres and Westcot, 1999).

\begin{tabular}{cccccc}
\hline qi & EC $(\mu \mathrm{S} / \mathrm{cm})$ & $\mathrm{SAR}$ & $\mathrm{Na}^{+}$ & $\mathrm{Cl}^{-}$ & $\mathrm{HCO}_{3}{ }^{-}$ \\
\cline { 4 - 6 } & & & \multicolumn{3}{c}{$\mathrm{meq} / \mathrm{l}$} \\
\hline $85-100$ & $200 \leq \mathrm{EC}<750$ & $2 \leq \mathrm{SAR}<3$ & $2 \leq \mathrm{Na}<3$ & $1 \leq \mathrm{Cl}<4$ & $1 \leq \mathrm{HCO} 3<1.5$ \\
$60-85$ & $750 \leq \mathrm{EC}<1500$ & $3 \leq \mathrm{SAR}<6$ & $3 \leq \mathrm{Na}<6$ & $4 \leq \mathrm{Cl}<7$ & $1.5 \leq \mathrm{HCO}<4.5$ \\
$35-60$ & $1500 \leq \mathrm{EC}<3000$ & $6 \leq \mathrm{SAR}<12$ & $6 \leq \mathrm{Na}<9$ & $7 \leq \mathrm{Cl}<10$ & $4.5 \leq \mathrm{HCO}<8.5$ \\
$0-35$ & $\mathrm{EC}<200$ or & $\begin{array}{c}\mathrm{SAR}<2 \text { or } \\
\mathrm{EC} \geq 3000\end{array}$ & $\begin{array}{c}\mathrm{Na}<2 \text { or } \\
\mathrm{Na} \geq 12\end{array}$ & $\mathrm{Cl}<1$ or & $\begin{array}{c}\mathrm{HCO} 3<1 \text { or } \\
\mathrm{HCO} \geq 8.5\end{array}$ \\
\hline
\end{tabular}

The following equation was used to calculate values of qi depending on the tolerance limits in Table (3).

$$
q_{i}=q_{\text {imax }}-\left\{\frac{\left[\left(x_{i j}-x_{i n f}\right) x q_{i a m p}\right]}{x_{a m p}}\right\}
$$

Where $q_{i m a x}$ is the maximum value of qi for the class; $X_{i j}$ is the detected value for the parameter; $x_{\text {inf }}$ is the corresponding value to the lower limit of the class to which the parameter belongs; $q_{i a m p}$ is class amplitude; $x_{a m p}$ is class amplitude to which the parameter belongs.

To evaluate $x_{a m p}$, of the last class for each parameter, the upper limit which determined in the water analysis was considered to be the highest value. Weight used in the IWQI of each parameter shows in Table (4).

The irrigation water quality index (IWQI) was calculated as:

$$
I W Q I=\sum_{i=1}^{n} q i \text { wi }
$$

IWQI is non- dimension parameter ranging from $(0-100) ; q_{i}$ is the quality of the $i^{\text {th }}$ parameter, a number from $(0-$ 100), function of its concentration or measurement; wi is the normalized weight of the $i^{\text {th }}$ parameter, function of its relative importance to water quality (Table 4). Division in classes was based on current water quality indexes. Definition of classes was considering the hazards of salinity problems, reduction of soil water infiltration and toxicity to plants which presented by Bernardo (1995) and Holanda and Amorim (1997). Water use restrictions as developed by Meireles et al (2010) are shown in (Table 5).

\section{Spatial interpolation of water properties}

Spatial distribution of water properties in the study area is widely used due to samples are collected at distinct locations for producing constant information (Ali and Moghanm, 2013). The method of interpolation was Inverse Distance Weighted (IDW) which uses measured values adjacent the estimate location. The closest measured values to the expectation location have more affection on the expected value than those further away, thus giving greater weight to points closest to the prediction. To interpolate water properties concentrations in the study area, the geostatistical relationships among points by GIS 10.4.1 software (spatial interpolation method (IDW) extension) were used. 
Radwa A. El Behairy, et al.,

Table (4): Weights for the IWQI parameters (Meireles et al., 2010).

\begin{tabular}{ll}
\hline Parameter & Weight $\left(\mathbf{w}_{\mathrm{i}}\right)$ \\
\hline $\mathrm{EC}$ & 0.211 \\
$\mathrm{Na}$ & 0.204 \\
$\mathrm{HCO}_{3}$ & 0.202 \\
$\mathrm{Cl}$ & 0.194 \\
$\mathrm{SAR}$ & 0.189 \\
\hline Total & 1.0 \\
\hline
\end{tabular}

Table (5): Water Quality Index Characteristics (Meireles et al., 2010).

\begin{tabular}{|c|c|c|c|}
\hline \multirow[b]{2}{*}{ IWQI } & \multirow[b]{2}{*}{$\begin{array}{l}\text { Water Use } \\
\text { Restrictions }\end{array}$} & \multicolumn{2}{|c|}{ Recommendation } \\
\hline & & Soil & Plant \\
\hline 85-100 & $\begin{array}{l}\text { No } \\
\text { Restriction } \\
\text { (NR) }\end{array}$ & $\begin{array}{l}\text { May be used for the majority of soils with } \\
\text { low probability of causing salinity and } \\
\text { sodicity problems, being recommended } \\
\text { leaching within irrigation practices, } \\
\text { except for in soils with extremely low } \\
\text { permeability. }\end{array}$ & $\begin{array}{l}\text { No toxicity risk for most } \\
\text { plants }\end{array}$ \\
\hline $70-85$ & $\begin{array}{l}\text { Low } \\
\text { Restriction } \\
\quad \text { (LR) }\end{array}$ & $\begin{array}{l}\text { Recommended for use in irrigated soils } \\
\text { with light texture or moderate } \\
\text { permeability, being recommended salt } \\
\text { leaching. Soil sodicity in heavy texture } \\
\text { soils may occur, being recommended to } \\
\text { avoid its use in soils with high clay. }\end{array}$ & Avoid salt sensitive plants \\
\hline $55-70$ & $\begin{array}{l}\text { Moderate } \\
\text { Restriction } \\
\quad(\mathrm{MR})\end{array}$ & $\begin{array}{l}\text { May be used in soils with moderate to } \\
\text { high permeability values, being } \\
\text { suggested moderate leaching of salts. }\end{array}$ & $\begin{array}{l}\text { Plants with moderate } \\
\text { tolerance to salts may be } \\
\text { grown }\end{array}$ \\
\hline $40-55$ & $\begin{array}{l}\text { High } \\
\text { Restriction } \\
\text { (HR) }\end{array}$ & $\begin{array}{l}\text { May be used in soils with high } \\
\text { permeability without compact layers. } \\
\text { High frequency irrigation schedule } \\
\text { should be adopted for water with EC } \\
\text { above } 2000 \mu \mathrm{cm}^{-1} \text { and SAR above } 7.0 \text {. }\end{array}$ & $\begin{array}{l}\text { Should be used for } \\
\text { irrigation of plants with } \\
\text { moderate to high tolerance } \\
\text { to salts with special salinity } \\
\text { control practices, except } \\
\text { water with low } \mathrm{Na}, \mathrm{Cl} \text { and } \\
\mathrm{HCO}_{3} \text { values }\end{array}$ \\
\hline $0-40$ & $\begin{array}{l}\text { Severe } \\
\text { Restriction } \\
\text { (SR) }\end{array}$ & $\begin{array}{l}\text { Should be avoided its use for irrigation } \\
\text { under normal conditions. In special } \\
\text { cases, may be used occasionally. Water } \\
\text { with low salt levels and high SAR require } \\
\text { gypsum application. In high saline } \\
\text { content water soils must have high } \\
\text { permeability, and excess water should be } \\
\text { applied to avoid salt accumulation. }\end{array}$ & $\begin{array}{l}\text { Only plants with high salt } \\
\text { tolerance, except for waters } \\
\text { with extremely low values of } \\
\mathrm{Na}, \mathrm{Cl} \text { and } \mathrm{HCO}_{3} \text {. }\end{array}$ \\
\hline
\end{tabular}

\section{RESULTS AND DISCUSSION}

\section{Water properties distribution}

\subsection{Hazards of salinity}

Increasing of salts in the crop root zone cause salinity hazard due to reducing the water availability. Without, leaching the soil by low salt content water, the salinization of the soil is permanent process that makes agricultural lands inappropriate for cultivation (Khalaf and Hassan 2013). 
Salinity hazard take place when salts start to raise in the crop root zone reducing the amount of water available to the roots. As shown in (Figs 3 and 4 ) and (Tables 6-9), the salinity of water samples in the study area is ranged between 492 and $4720 \mu \mathrm{S} / \mathrm{cm}$ with average value of (1648.57) $\mu \mathrm{S} / \mathrm{cm}$. The salinity values increase to east. This might be due to a lot of drains discharge to irrigation canals and farmers use these canals for irrigation without any treatments. The data reveal that, the EC values vary widely as Standard Division (STD) equal to (1205.69). According to Scofield (1936) values, six water resources are good for irrigation and the rest of resources are differed between permissible and doubtful classes except sample from canal 2 is unsuitable for irrigation (Table 8). Considering that, the irrigation water standard based on FAO (1985), the results of study area vary from none to slight moderate but have dropped in canal No 2 to severe degree of restriction (Table 9).

\subsection{Specific Ion Toxicity}

A common toxicity symptom ofthe sodium ion is Leaf burn, scurvy and dead fabric on the exterior edges of the leaves (Khalaf and Hassan, 2013). The $\mathrm{Na}^{+}$ concentrations of water samples Tables (6 and 7) ranged from $5.62 \mathrm{meq} / \mathrm{l}$ to 36.5 meq/l with mean concentration of 15.22 meq/l. High variation of $\mathrm{Na}^{+}$was noticed (STD=9.17) as shown in Table (7). The spatial trends showed that, concentrations increased from north west to east (Fig, 5). The data of $\left(\mathrm{Na}^{+}\right)$ concentrations indicate that, based on Scofield, (1936) most of water resources of study area are under class 2 except for canals 2, 3 and 14 which are in C3 and C1, respectively (Table 8 and Fig 6).

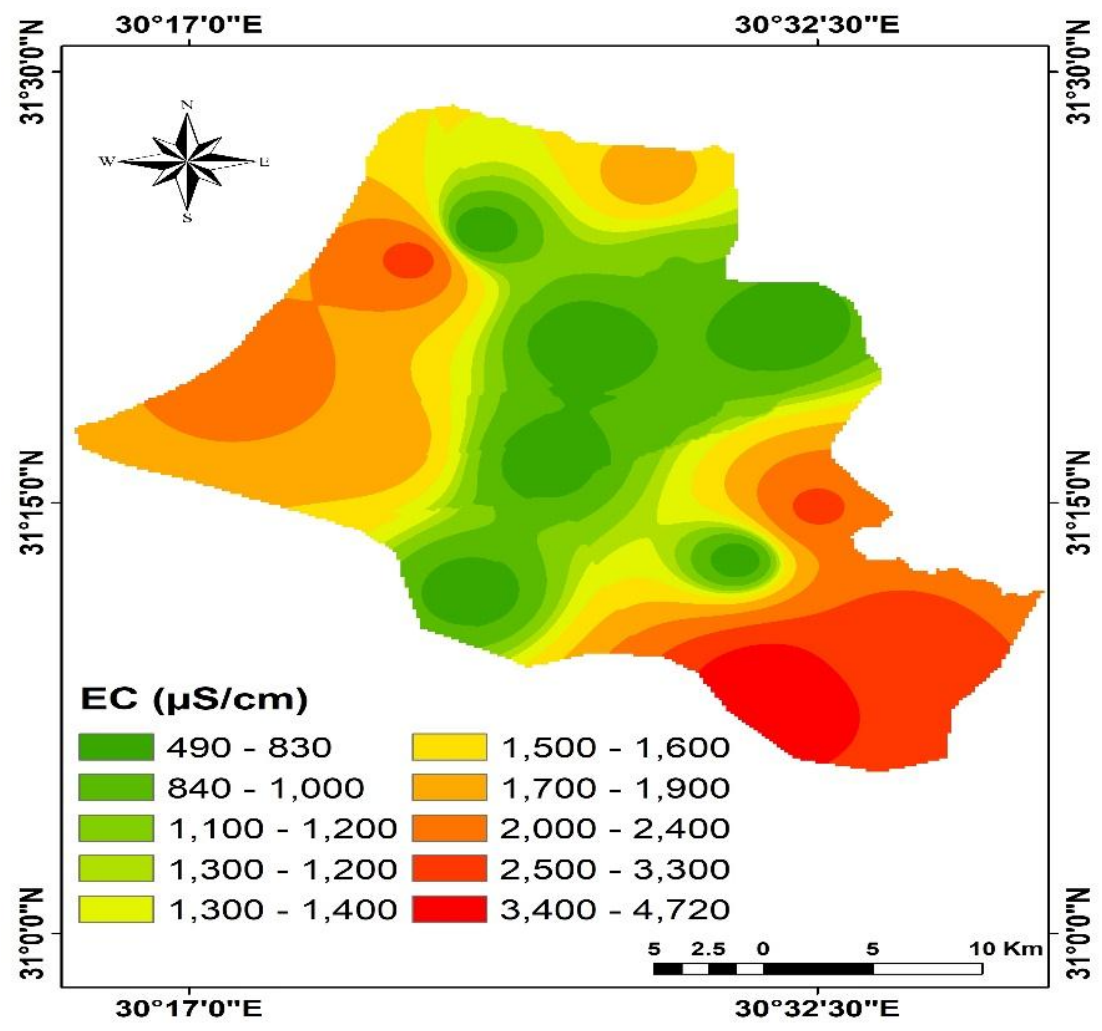

Fig (3): Interpolated map of EC in study area. 
Radwa A. El Behairy, et al.,

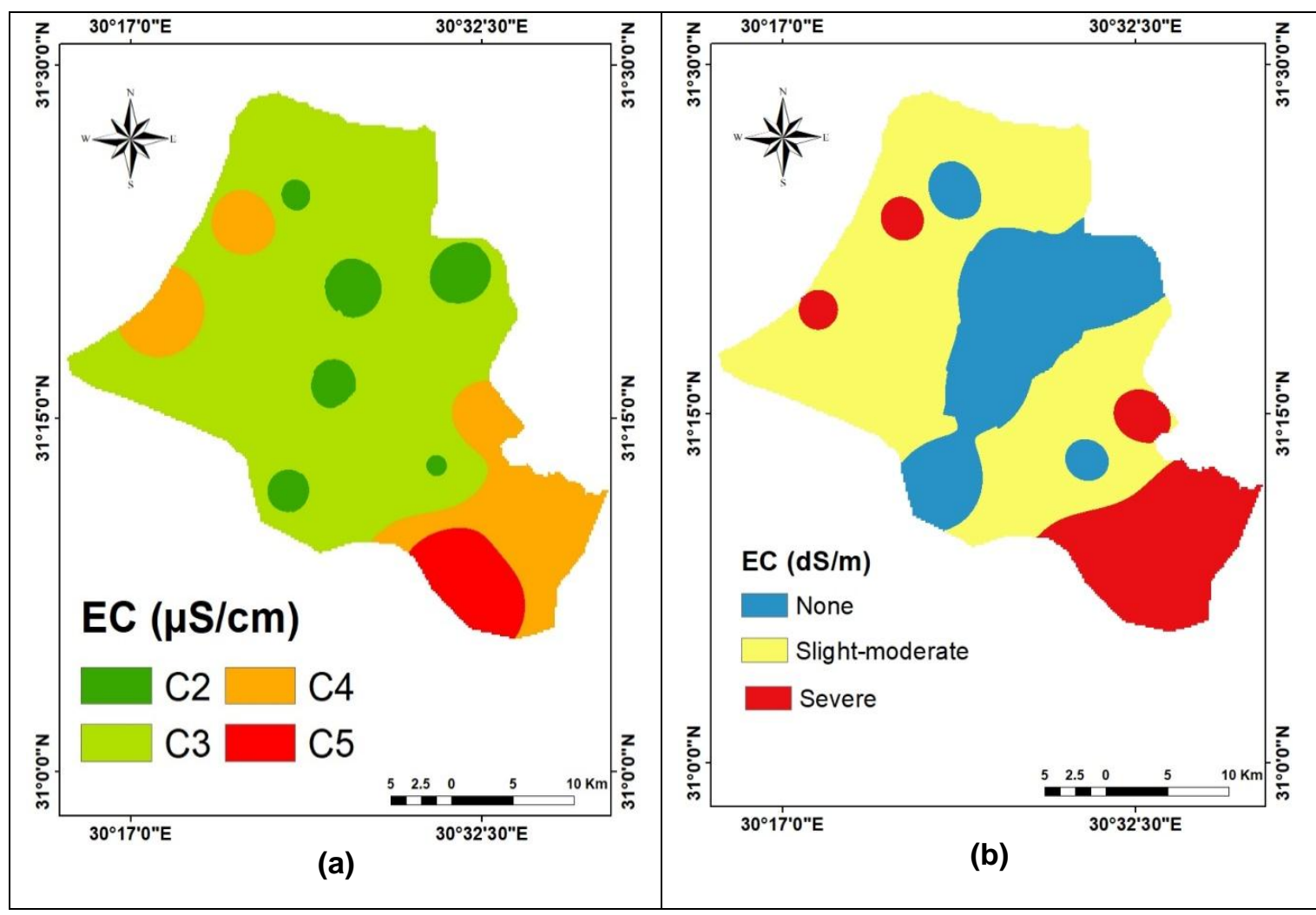

Fig (4): Classes of water EC according to (a) Scofield (1936) and (b) FAO (1985).

Table (6): Parameters of Water Quality analysis in the Study Area.

\begin{tabular}{|c|c|c|c|c|c|c|c|c|c|c|c|}
\hline \multirow{2}{*}{$\begin{array}{c}\text { Sample } \\
\text { No. }\end{array}$} & \multirow{2}{*}{ pH } & \multirow{2}{*}{$\begin{array}{c}\text { EC } \\
\mu \mathrm{S} / \mathrm{cm}\end{array}$} & \multirow{2}{*}{$\begin{array}{c}\mathrm{Na}^{+} \\
\mathrm{mg} / \mathrm{L}\end{array}$} & \multicolumn{4}{|c|}{ Cations (meq / L) } & \multicolumn{3}{|c|}{ Anions (meq/L) } & \multirow{2}{*}{ SAR } \\
\hline & & & & $\mathrm{Na}^{+}$ & $\mathrm{K}^{+}$ & $\mathrm{Ca}^{+2}$ & $\mathrm{Mg}^{+2}$ & $\mathrm{HCO}_{3}{ }^{-}$ & $\mathrm{CL}^{-}$ & $\mathrm{SO}_{4}^{-2}$ & \\
\hline 1 & 6.95 & 2630 & 484.38 & 21.06 & 0.54 & 3.2 & 7.2 & 7.6 & 11.2 & 13.2 & 9.24 \\
\hline 2 & 7.33 & 4720 & 839.5 & 36.5 & 0.82 & 7 & 11.2 & 6.4 & 30 & 19.12 & 12.1 \\
\hline 3 & 7.14 & 2720 & 549.01 & 23.87 & 0.59 & 3.8 & 6.4 & 8.2 & 14.4 & 12.06 & 10.57 \\
\hline 4 & 7.17 & 1905 & 355.35 & 15.45 & 0.52 & 3.2 & 4.4 & 5.2 & 10.4 & 7.97 & 7.93 \\
\hline 5 & 7.02 & 2330 & 452.18 & 19.66 & 0.61 & 3.4 & 5.4 & 7.4 & 13.8 & 7.87 & 9.37 \\
\hline 6 & 7.17 & 492 & 149.73 & 6.51 & 0.23 & 2 & 2.6 & 3.6 & 1.8 & 5.94 & 4.29 \\
\hline 7 & 7.02 & 500 & 149.73 & 6.51 & 0.21 & 2.6 & 1.4 & 3.8 & 1.8 & 5.12 & 4.60 \\
\hline 8 & 6.82 & 540 & 149.73 & 6.51 & 0.19 & 2.6 & 1.8 & 3.6 & 1.8 & 5.7 & 4.39 \\
\hline 9 & 7.78 & 637 & 187.91 & 8.17 & 0.21 & 3 & 2.2 & 4 & 1.8 & 7.78 & 5.07 \\
\hline 10 & 7.46 & 624 & 226.09 & 9.83 & 0.23 & 2.6 & 3 & 4.2 & 1.8 & 9.66 & 5.87 \\
\hline 11 & 7.45 & 621 & 187.91 & 8.17 & 0.23 & 2.6 & 2.6 & 4 & 2.4 & 7.2 & 5.07 \\
\hline 12 & 7.15 & 2580 & 419.75 & 18.25 & 2.07 & 4.2 & 4.8 & 4.2 & 13.6 & 11.52 & 8.60 \\
\hline 13 & 8.13 & 1029 & 129.26 & 5.62 & 0.28 & 2.8 & 2.8 & 4.4 & 4.6 & 2.5 & 3.35 \\
\hline 14 & 8.09 & 1752 & 621.46 & 27.02 & 0.47 & 3.2 & 4.6 & 5.8 & 16.2 & 13.29 & 13.68 \\
\hline
\end{tabular}


Assessment and mapping of surface water quality index for irrigation

Table (7): The statistical properties of the water properties in the study area.

\begin{tabular}{cccccc}
\hline Parameters & Unit & Maximum & Minimum & Average & $\begin{array}{c}\text { Standard } \\
\text { Deviation }\end{array}$ \\
\hline $\mathrm{pH}$ & - & 8.13 & 6.82 & 7.33 & 0.39 \\
$\mathrm{EC}$ & $\mu \mathrm{S} / \mathrm{cm}$ & 4720 & 492 & 1648.57 & 1205.69 \\
$\mathrm{Na}$ & $\mathrm{mg} / \mathrm{L}$ & 839.5 & 129.26 & 350.14 & 210.99 \\
$\mathrm{~K}$ & $\mathrm{meq} / \mathrm{L}$ & 36.5 & 5.62 & 15.22 & 9.17 \\
$\mathrm{Ca}$ & $\mathrm{meq} / \mathrm{L}$ & 2.07 & 0.19 & 0.51 & 0.47 \\
$\mathrm{Mg}$ & $\mathrm{meq} / \mathrm{L}$ & 7 & 2 & 3.3 & 1.16 \\
$\mathrm{HcO}{ }_{3}$ & $\mathrm{meq} / \mathrm{L}$ & 11.2 & 1.4 & 4.31 & 2.55 \\
$\mathrm{Cl}$ & $\mathrm{meq} / \mathrm{L}$ & 5 & 3.6 & 4.14 & 0.44 \\
$\mathrm{SO}_{4}$ & $\mathrm{meq} / \mathrm{L}$ & 30 & 1.8 & 8.97 & 7.99 \\
$\mathrm{SAR}^{\mathrm{meq} / \mathrm{L}}$ & 19.12 & 2.5 & 9.21 & 4.13 \\
& - & 13.68 & 3.36 & 7.44 & 3.12 \\
\hline
\end{tabular}

Table (8): Irrigation Water Quality Classes according to Scofield, (1936) in the Study Area.

\begin{tabular}{|c|c|c|c|c|c|c|c|c|}
\hline $\begin{array}{c}\text { Sample } \\
\text { No. }\end{array}$ & $\begin{array}{c}\text { EC } \\
\mu s / c m\end{array}$ & Classification & $\begin{array}{l}\mathrm{Na}^{+} \\
\mathrm{mg} / \mathrm{l}\end{array}$ & Classification & $\begin{array}{c}\mathrm{Cl}^{-} \\
\mathrm{meq} / \mathrm{l}\end{array}$ & $\begin{array}{l}\text { Classificati } \\
\text { on }\end{array}$ & $\begin{array}{l}\mathrm{SO}_{4}^{-} \\
\mathrm{meq} / \mathrm{l}\end{array}$ & Classification \\
\hline 1 & 2630 & C4 & 484.38 & $\mathrm{C} 2$ & 11.2 & C3 & 13.2 & C4 \\
\hline 2 & 4720 & C5 & 839.5 & $\mathrm{C} 3$ & 30 & C5 & 19.12 & C4 \\
\hline 3 & 2720 & C4 & 549.01 & C3 & 14.4 & C4 & 12.06 & C4 \\
\hline 4 & 1905 & C3 & 355.35 & $\mathrm{C} 2$ & 10.4 & C3 & 7.97 & C3 \\
\hline 5 & 2330 & C4 & 452.18 & $\mathrm{C} 2$ & 13.8 & C4 & 7.87 & C3 \\
\hline 6 & 492 & C2 & 149.73 & C1 & 1.8 & C1 & 5.94 & $\mathrm{C} 2$ \\
\hline 7 & 500 & C2 & 149.73 & C1 & 1.8 & C1 & 5.12 & $\mathrm{C} 2$ \\
\hline 8 & 540 & $\mathrm{C} 2$ & 149.73 & C1 & 1.8 & $\mathrm{C} 1$ & 5.7 & $\mathrm{C} 2$ \\
\hline 9 & 637 & C2 & 187.91 & $\mathrm{C} 2$ & 1.8 & C1 & 7.78 & C3 \\
\hline 10 & 624 & C2 & 226.09 & $\mathrm{C} 2$ & 1.8 & C1 & 9.66 & C3 \\
\hline 11 & 621 & C2 & 187.91 & C2 & 2.4 & C1 & 7.2 & C3 \\
\hline 12 & 2580 & C4 & 419.75 & $\mathrm{C} 2$ & 13.6 & C4 & 11.52 & C3 \\
\hline 13 & 1029 & C3 & 129.26 & C1 & 4.6 & $\mathrm{C} 2$ & 2.5 & C1 \\
\hline 14 & 1752 & C3 & 621.46 & C3 & 16.2 & C4 & 13.29 & C4 \\
\hline
\end{tabular}

The interpolation of chloride ion $\left(\mathrm{Cl}^{-}\right)$ shows high spatial variability, with the lowest values $(1.8 \mathrm{meq} / \mathrm{l})$ in canals $(6-10)$ and the highest concentration (30 meq/l) in canal 2 (Fig, 5). In view of the standard deviation, in Table (7) it is observed that, the variation of $\mathrm{Cl}$ is very wide (STD= 7.99). Chloride can have absorbed by plants easily and if it'sconcentration in the leaves exceeds the tolerance of plant, signs of injury such as leaf burns or leaf tissue drying occur (Ayers and Westco, 1985). The $\mathrm{Cl}$ concentrations in Table (8) and Fig (6) showed that, water samples were in five classes from $\mathrm{C} 1$ to $\mathrm{C5}$ Scofield, (1936). 
Radwa A. El Behairy, et al.,

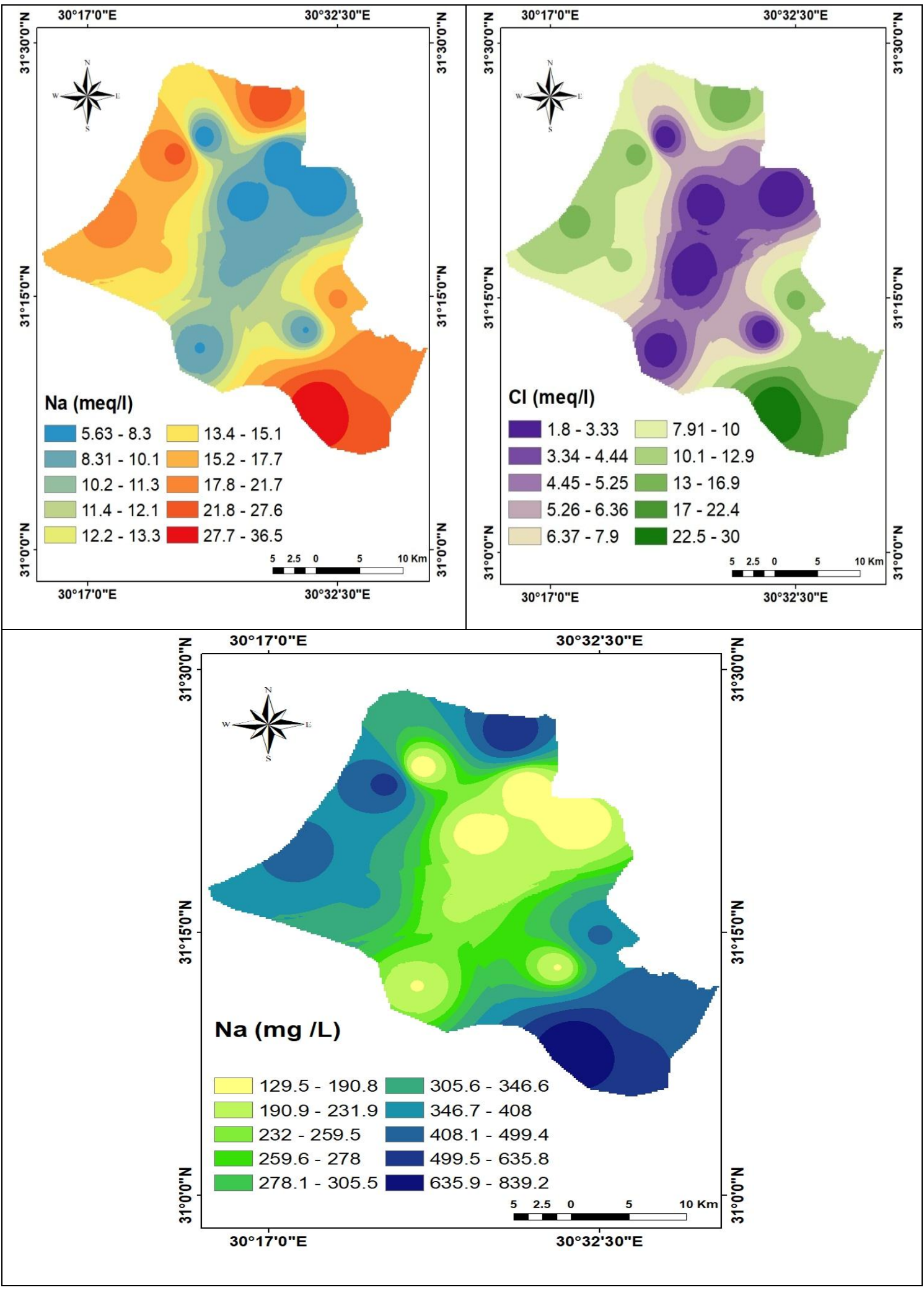

Fig (5): Interpolated map of Specific lon Toxicity in study area. 


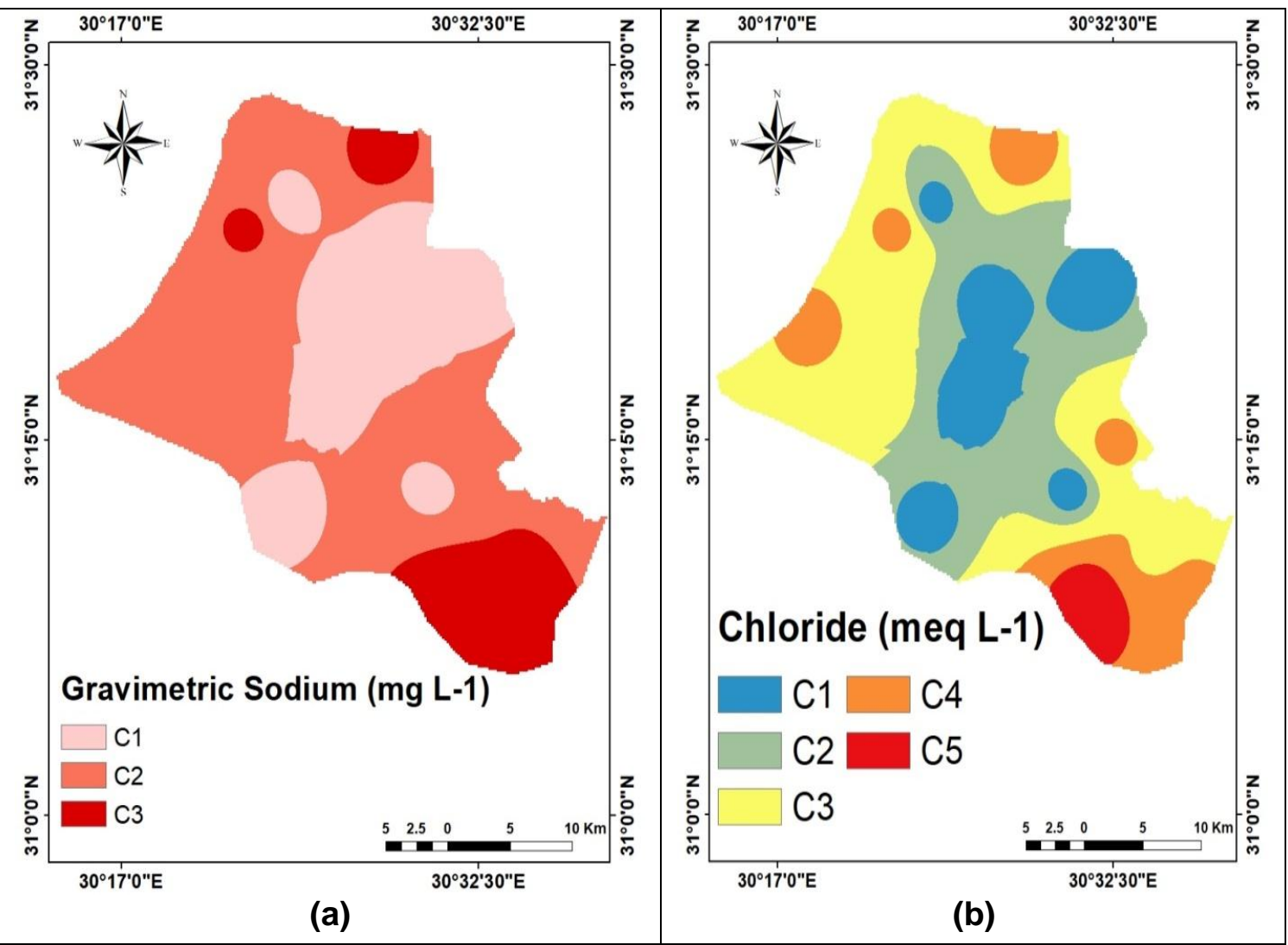

Fig (6): Classes of water Specific lon Toxicity according to (a) Scofield (1936) and (b)FAO (1985).

Table (9): Irrigation Water Quality Classes according to FAO (1985) in the Study Area.

\begin{tabular}{|c|c|c|c|c|c|c|c|c|c|c|c|c|c|}
\hline $\begin{array}{c}\text { Sample } \\
\text { No }\end{array}$ & $\begin{array}{c}\mathrm{EC} \\
\mathrm{dS} / \mathrm{m}\end{array}$ & $\begin{array}{l}\text { Degree of } \\
\text { restriction }\end{array}$ & SAR & $\begin{array}{c}E C \\
(\mathrm{dS} / \mathrm{m})\end{array}$ & $\begin{array}{l}\text { Degree of } \\
\text { restriction }\end{array}$ & f SAR & $\begin{array}{l}\text { Degree of } \\
\text { restriction( }\end{array}$ & $\begin{array}{c}\mathrm{Cl}^{-} \\
(\mathrm{meq} / \mathrm{L})\end{array}$ & $\begin{array}{l}\text { Degree of } \\
\text { restriction }\end{array}$ & $\begin{array}{l}\mathrm{HCO}_{3}{ }^{-} \\
(\mathrm{meq} / \mathrm{L}\end{array}$ & $\begin{array}{l}\text { Degree of } \\
\text {-)restriction }\end{array}$ & $\mathrm{pH}$ & $\begin{array}{c}\text { Degree of } \\
\text { restriction }\end{array}$ \\
\hline 1 & 2.63 & SI - M & 9.24 & 2.63 & $\mathbf{N}$ & 9.24 & S & 11.2 & S & 4.4 & $S I-M$ & 6.95 & Normal \\
\hline 2 & 4.72 & S & 12.1 & 4.72 & $\mathbf{N}$ & 12.1 & $\mathrm{~s}$ & 30 & s & 4 & $S I-M$ & 7.33 & Normal \\
\hline 3 & 2.72 & $S I-M$ & 10.57 & 2.72 & $\mathbf{N}$ & 10.57 & $\mathrm{~S}$ & 14.4 & s & 5 & $S I-M$ & 7.14 & Normal \\
\hline 4 & 1.91 & SI - M & 7.93 & 1.91 & $S I-M$ & 7.93 & $S I-M$ & 10.4 & S & 3.6 & $S I-M$ & 7.17 & Normal \\
\hline 5 & 2.33 & $S I-M$ & 9.37 & 2.33 & $\mathbf{N}$ & 9.37 & $S$ & 13.8 & S & 5 & $S I-M$ & 7.02 & Normal \\
\hline 6 & 0.49 & $\mathbf{N}$ & 4.29 & 0.49 & $S I-M$ & 4.29 & $S I-M$ & 1.8 & $\mathbf{N}$ & 3.6 & $S I-M$ & 7.17 & Normal \\
\hline 7 & .5 & $\mathbf{N}$ & 4.60 & 0.5 & $S I-M$ & 4.60 & $S I-M$ & 1.8 & $\mathbf{N}$ & 3.8 & $S I-M$ & 7.02 & Normal \\
\hline 8 & 0.54 & $\mathbf{N}$ & 4.39 & 0.54 & $S I-M$ & 4.39 & $S I-M$ & 1.8 & $\mathbf{N}$ & 3.6 & $S I-M$ & 6.82 & Normal \\
\hline 9 & 0.64 & $\mathbf{N}$ & 5.07 & 0.64 & $S I-M$ & 5.07 & $S I-M$ & 1.8 & $\mathbf{N}$ & 4 & $S I-M$ & 7.78 & Normal \\
\hline 10 & 0.62 & $\mathbf{N}$ & 5.87 & 0.62 & SI - M & 5.87 & $S I-M$ & 1.8 & $\mathbf{N}$ & & SI - M & 7.46 & Normal \\
\hline 11 & 0.62 & $\mathbf{N}$ & 5.07 & 0.62 & $S I-M$ & 5.07 & $S I-M$ & 2.4 & $\mathbf{N}$ & 4 & $S I-M$ & 7.45 & Normal \\
\hline 12 & 2.58 & SI - M & 8.60 & 2.58 & $\mathbf{N}$ & 8.60 & $S I-M$ & 13.6 & s & 4.2 & $S I-M$ & 7.15 & Normal \\
\hline 13 & 1.03 & $S I-M$ & 3.35 & 1.03 & $S I-M$ & 3.35 & $S I-M$ & 4.6 & $S I-M$ & 4.4 & $S I-M$ & 8.13 & Normal \\
\hline 14 & 1.75 & SI - M & 13.68 & 1.75 & $\mathbf{S I}-\mathbf{M}$ & 13.68 & s & 16.2 & s & 4.2 & SI - M & 8.09 & Normal \\
\hline
\end{tabular}

*SI-M = Slight -Moderate, $\quad$ SI= Slight, $\quad M=$ Moderate, $\quad S=$ Severe, $\quad$ N= None 
Radwa A. El Behairy, et al.,

\subsection{Permeability and Infiltration Hazard}

The sodium adsorption ratio (SAR) is the most common water quality factor that influences the normal rate of infiltration and it is used to evaluate $\mathrm{Na}^{+}$ ions tendency for adsorption on soil. It evaluates the sodium hazard in relation to $\mathrm{Ca}^{+2}$ plus $\mathrm{Mg}^{+2}$ in irrigation water concentrations (Miller and Gardiner, 2007). Generally, the higher SAR values, the larger the risk of sodium hazard on plant growth. The high content of SAR in the irrigation water influences the soil restriction, reduces aeration and permeability, and also resulting in alkaline soil which can affect plant growth. The concept of it used for dedication of probable sodium hazard (Almeida et al., 2008). Sodium adsorption ratio was calculated according to the following equation of Richards (1954) (All values in $\mathrm{meq} / \mathrm{L}$ ):

$$
\mathrm{SAR}=\mathrm{Na}^{+} /\left[\left(\mathrm{Ca}^{+2}+\mathrm{Mg}^{+2}\right) / 2\right]^{1 / 2}(3)
$$

The calculated value of SAR in the investigated area were within the usual range in the irrigation water $(0-15$ $\mathrm{meq} / \mathrm{L})$. It ranged from 3.36 to 13.68 (Tables 6 and 7 as well as Fig 7). Nine water samples are slight moderate for irrigation and the rest of samples are cause none problems for soils and plant if these samples used for irrigation according to FAO 1985 classification (Fig 8).

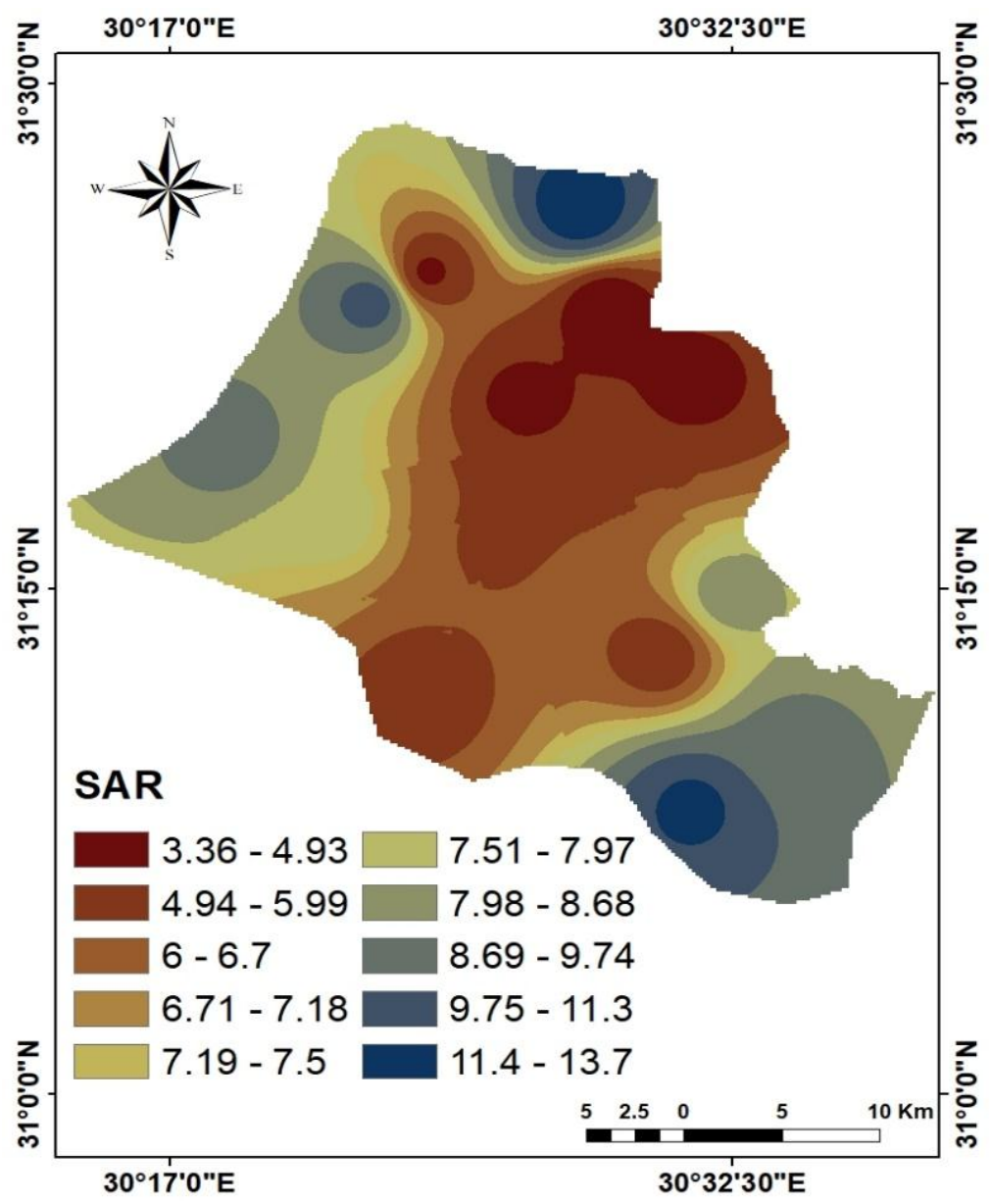

Fig (7): Interpolated map of SAR of study area. 


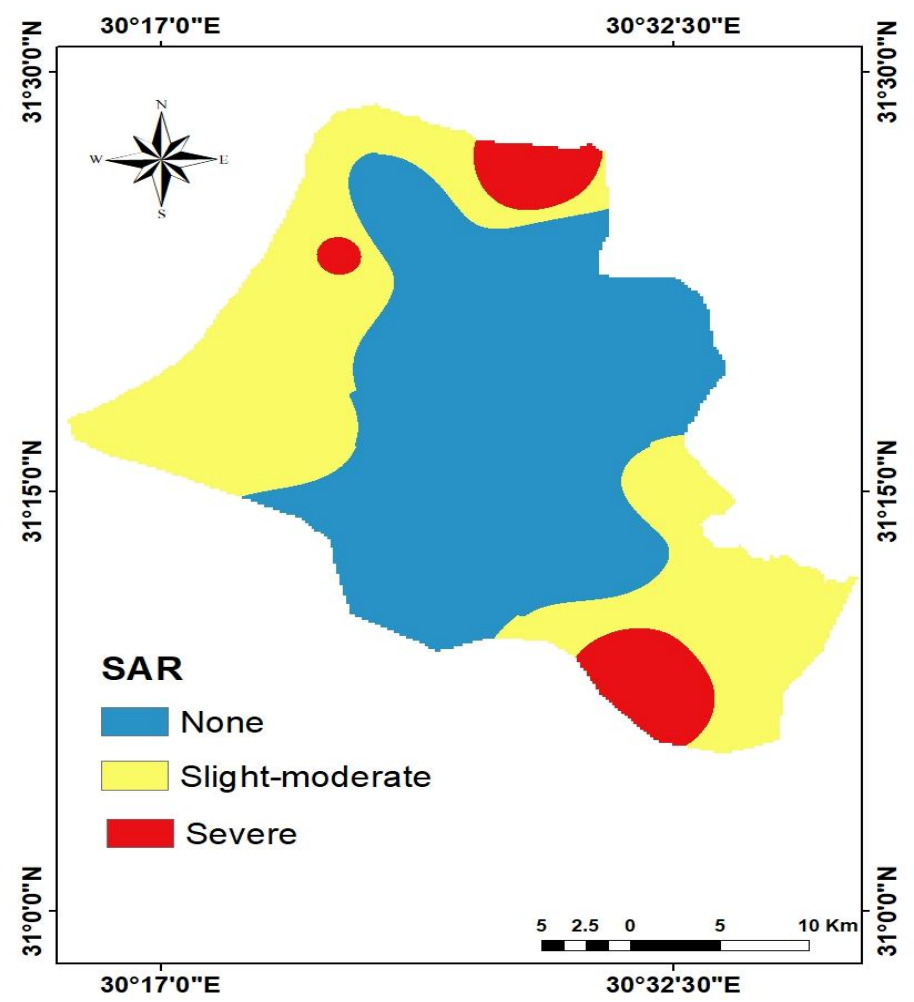

Fig (8): Classes of water SAR according to FAO (1985).

\subsection{Miscellaneous Effects}

The bicarbonates ion $\left(\mathrm{HCO}_{3}{ }^{-}\right)$ concentration of water samples ranged between $3.6 \mathrm{meq} / \mathrm{l}$ to $5.0 \mathrm{meq} / \mathrm{l}$ with mean value (4.14) $\mathrm{meq} / \mathrm{l}$. High concentrations of bicarbonates with high salinity together in the study area indicates a probable hydraulic connection with relatively unmineralized surface water (Jassim and Goff, 2006). The pH values of the collected water samples are ranged from 6.82 to 8.13 (Tables, 6 and 7). For the $\left(\mathrm{HCO}_{3}{ }^{-}\right)$and $\mathrm{pH}$ values slight variations were observed in the studied area where the STD ranges between 0.39 and 0.44 . All $\left(\mathrm{HCO}_{3}{ }^{-}\right)$concentrations were in the slight moderate restriction class for irrigation specified by FAO 1985, while $\mathrm{pH}$ values are in normal range (Fig, 9).

\subsection{Sulfate}

The Sulfate $\left(\mathrm{SO}_{4}{ }^{2-}\right)$ concentration of water samples ranged between $2.5 \mathrm{meq} / \mathrm{l}$ to $19.12 \mathrm{meq} / \mathrm{l}$ with mean value of 9.21 meq/l (Table, 6 and 7). In view of the standard deviation, it is observed that, the variation of $\mathrm{SO}_{4}{ }^{2-}$ is very wide (STD= 4.13) Table (7). The potential sources of $\mathrm{SO}_{4}{ }^{2-}$ ions in the irrigation canals of the study area may be derived from agricultural activities (fertilizer inputs) and/or domestic sewage. The spatial distribution of the sulfate concentration in the study area is shown in Fig (10). Where the figure showed that, the concentrations increased, then decreased, then increased again from the northeast to the south. The figure also showed that, the representative value of the water source (13) is the lowest and the representative value of the water source 2 is the highest. According to Scofield (1936) values, three water resources are located good for irrigation and the rest of resources are differing between permissible and doubtful classes except sample from canal 13 is excellent for irrigation (Table, 8 and Fig, 11). 
Radwa A. El Behairy, et al.,

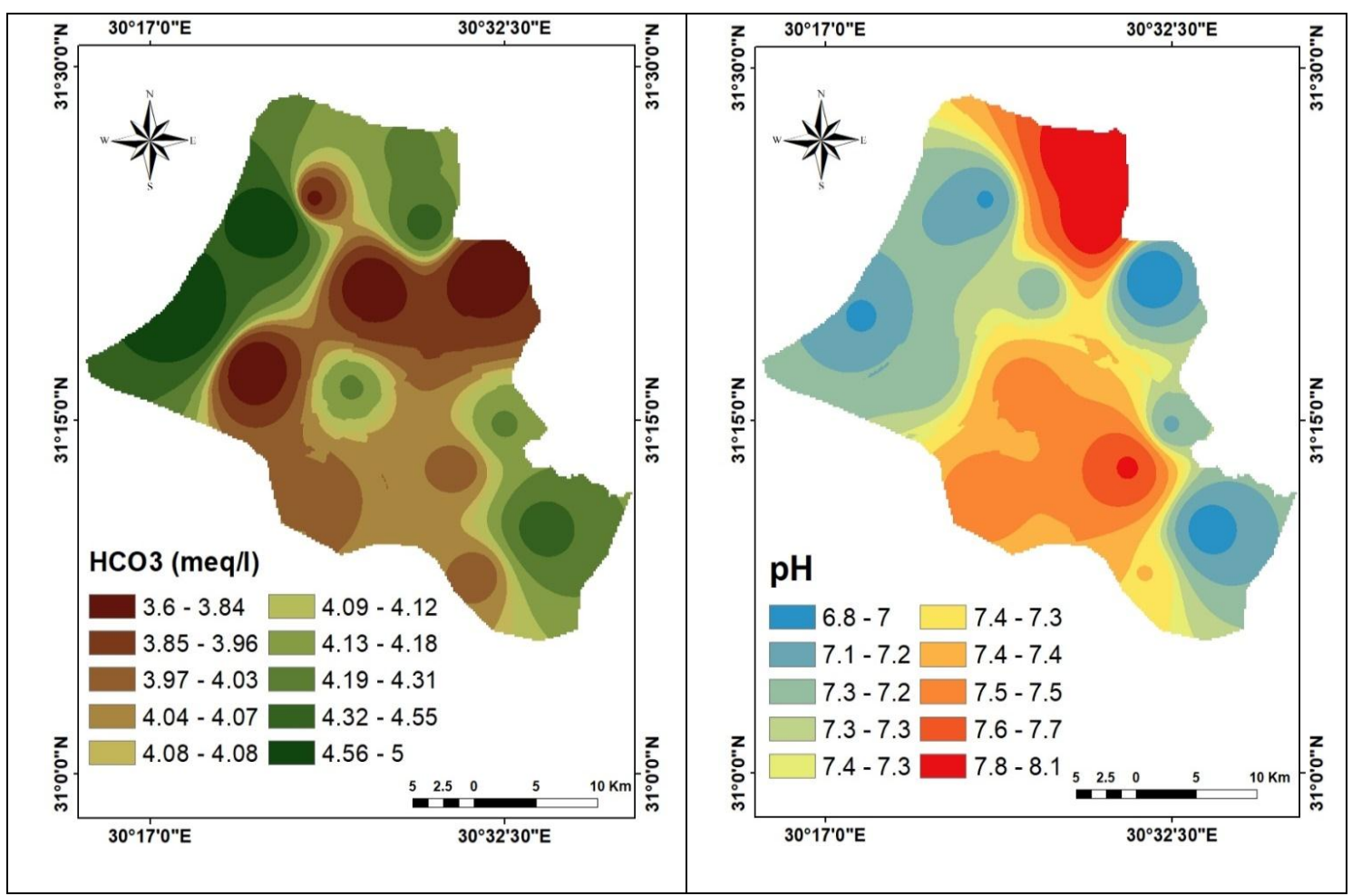

Fig (9): Interpolated maps of miscellaneous Effects.

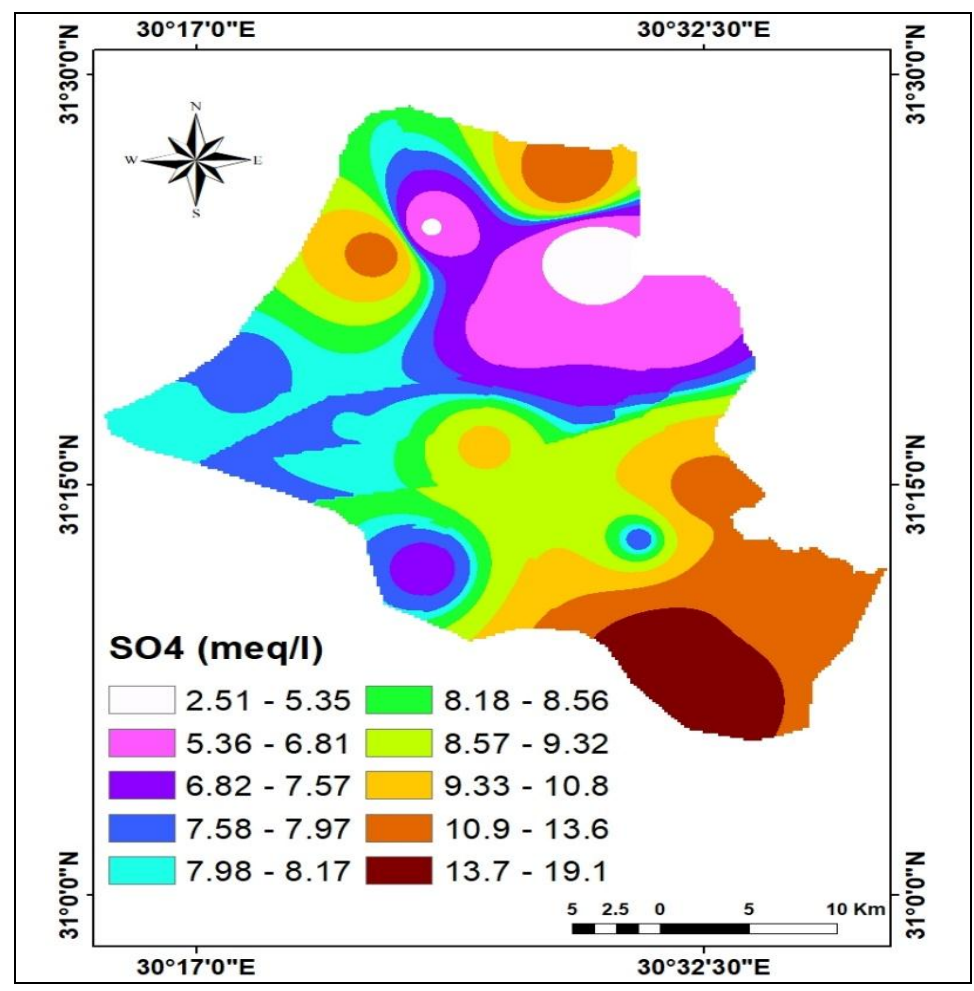

Fig (10): Interpolated map of Sulfate. 


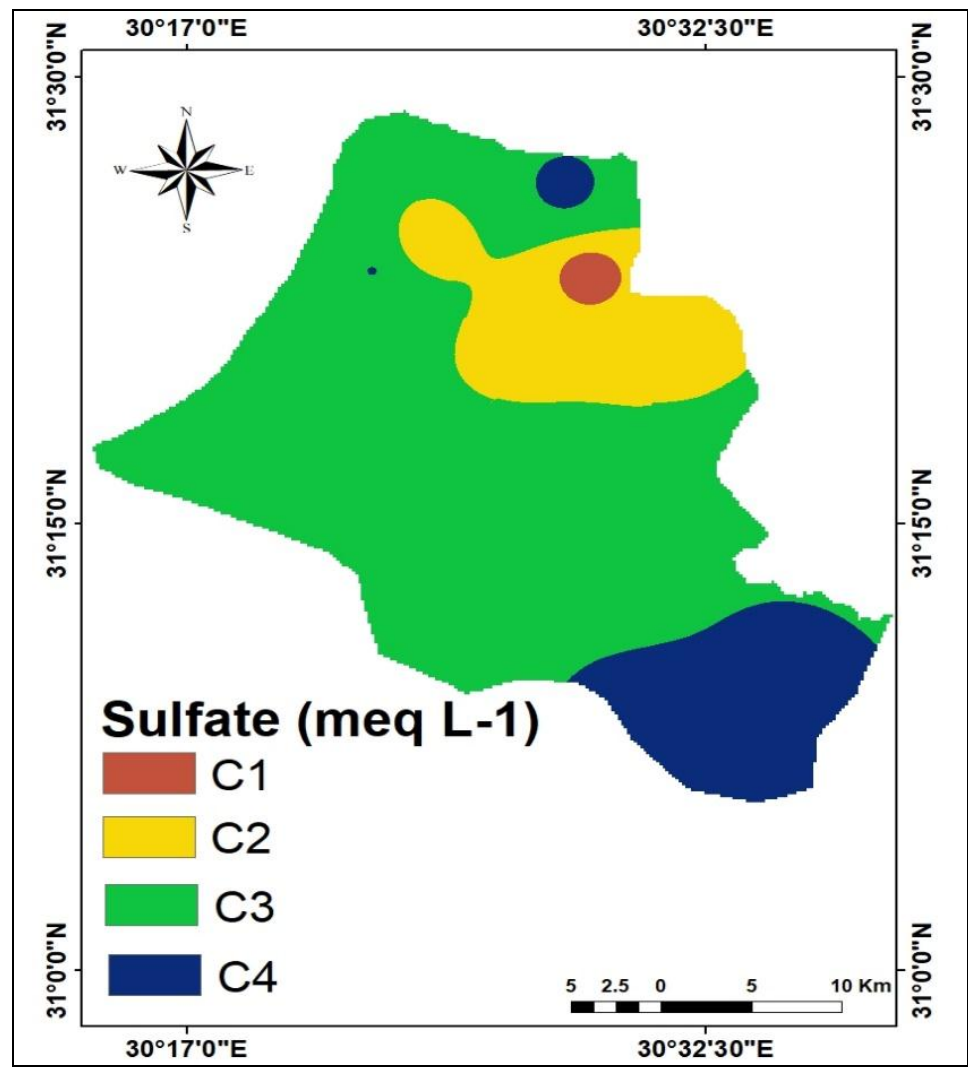

Fig (11): Classes of Sulfate according to (Scofield, 1936).

\section{Irrigation Water Quality Index}

\section{ArcGIS (10.4.1) Spatial Analyst} extension according to Equation $(1,2)$ was used for spatial integration of surface water quality mapping. This integration gives the IWQ index map which showed in (Fig, 12). The results reveal that, the IWQI values ranged from 1.07 to 76.43 (Table, 10). The IWQI spatial distribution in the study area shows that, samples fell into four classes, LR (178 $\left.\mathrm{km}^{2}\right)$, MR $\left(138 \mathrm{~km}^{2}\right)$, HR $\left(92 \mathrm{Km}^{2}\right)$ and SR $\left(249 \mathrm{~km}^{2}\right)$. The area of Severe restriction water quality would be cited in the southeast and northwest of study area due to increase the EC, SAR, $\left(\mathrm{Na}^{+}\right)$and $\left(\mathrm{CL}^{-}\right)$ion in this direction as shown in (Figs, 3 to 5) respectively. Water from these resources may causing adverse impact on soil properties and productivity. According to the recommendation in (Table, 5) most of surface water in the study area may avoided its use for irrigation under normal conditions, and should be used wealth high permeability soils, and with high salt tolerance plants with spatial salinity practises. 
Radwa A. El Behairy, et al.,

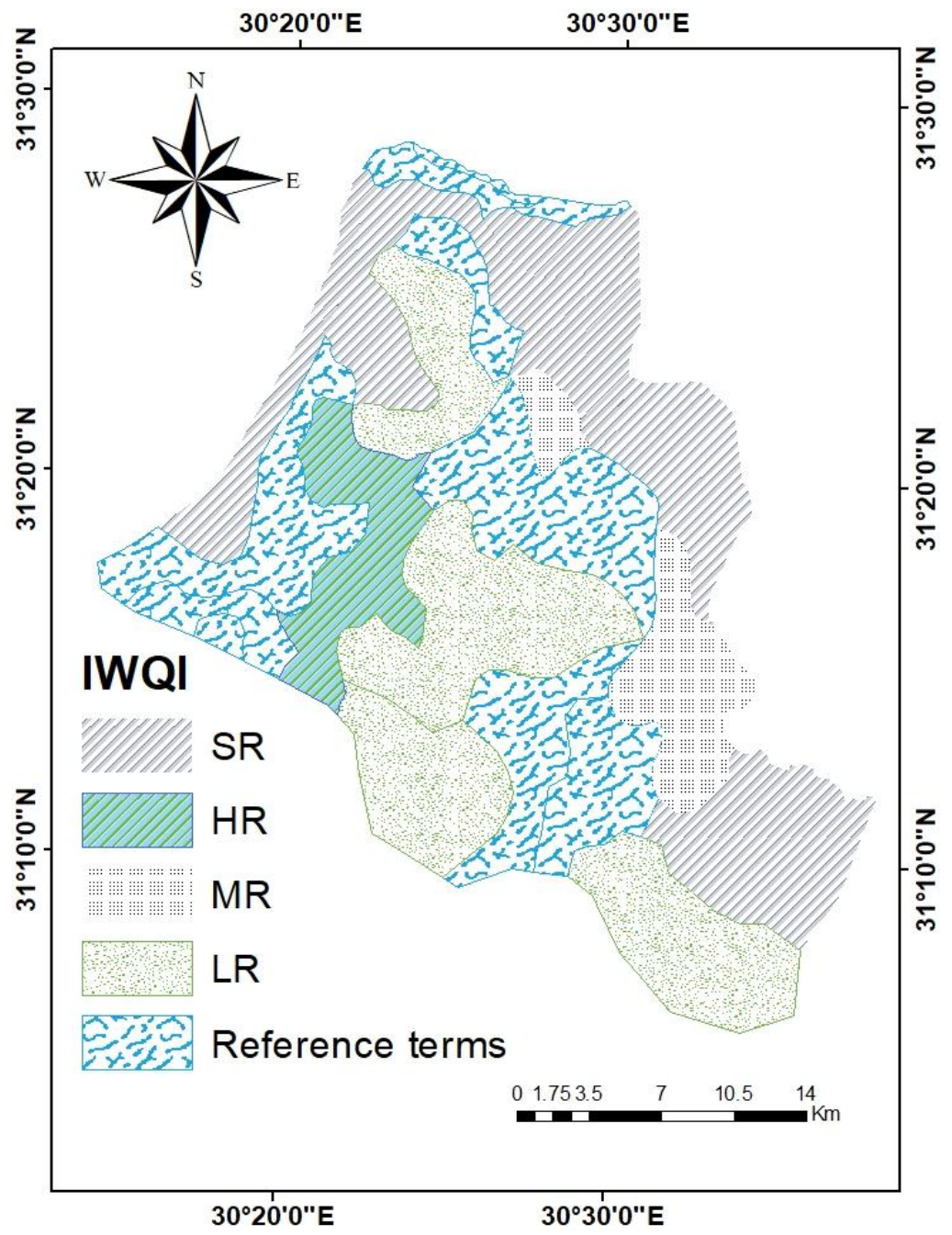

Fig (12): Map of Irrigation Water Quality Index (IWQI) in the study area.

Table (10): The Results of Irrigation Water Quality Index (IWQI) in the Study Area.

\begin{tabular}{|c|c|c|c|c|c|c|c|c|c|c|c|c|}
\hline $\begin{array}{c}\text { Sample } \\
\text { No. }\end{array}$ & $\begin{array}{c}E C \\
\mu s / c m\end{array}$ & $q^{i^{*} w i}$ & SAR & $q i^{*} w i$ & $\begin{array}{c}\mathrm{Na}^{+} \\
\mathrm{meq} / \mathrm{L}\end{array}$ & $q i^{*} w i$ & $\begin{array}{c}\mathrm{Cl}^{-} \\
\mathrm{meq} / \mathrm{L}\end{array}$ & $q i^{*} w i$ & $\begin{array}{l}\mathrm{HCO}_{3}{ }^{-} \\
\mathrm{meq} / \mathrm{L}\end{array}$ & $q i^{*} w i$ & IWQI & $\begin{array}{l}\text { Water Use } \\
\text { Restrictions }\end{array}$ \\
\hline 1 & 2630 & 8.69 & 9.24 & 8.8 & 21.06 & $\begin{array}{l}-2.43 \\
\end{array}$ & 11.2 & 5.97 & 4.4 & 12.12 & 33.15 & SR \\
\hline 2 & 4720 & 3.15 & 12.09 & 6.57 & 36.5 & -14.68 & 30 & -6.79 & 4 & 12.82 & 1.07 & SR \\
\hline 3 & 2720 & 8.37 & 10.57 & 7.74 & 23.87 & -4.66 & 14.4 & 3.80 & 5 & 11.47 & 26.73 & SR \\
\hline 4 & 1905 & 11.24 & 7.93 & 9.83 & 15.45 & 2.02 & 10.4 & 6.52 & 3.6 & 13.51 & 43.12 & HR \\
\hline 5 & 2330 & 9.74 & 9.37 & 8.69 & 19.66 & -1.32 & 13.8 & 4.21 & 5 & 11.47 & 32.79 & SR \\
\hline 6 & 492 & 19.42 & 4.29 & 14.03 & 6.51 & 11.37 & 1.8 & 18.09 & 3.6 & 13.51 & 76.43 & LR \\
\hline 7 & 500 & 19.37 & 4.60 & 13.55 & 6.51 & 11.37 & 1.8 & 18.09 & 3.8 & 13.17 & 75.55 & LR \\
\hline 8 & 540 & 19.14 & 4.39 & 13.89 & 6.51 & 11.37 & 1.8 & 18.09 & 3.6 & 13.51 & 76.01 & LR \\
\hline 9 & 637 & 18.59 & 5.07 & 12.82 & 8.17 & 8.55 & 1.8 & 18.09 & 4 & 12.82 & 70.86 & LR \\
\hline 10 & 624 & 18.66 & 5.87 & 11.54 & 9.83 & 6.48 & 1.8 & & 4.2 & & & \\
\hline 11 & 621 & 18.68 & 5.07 & 12.82 & 8.17 & 8.55 & 2.4 & 17.65 & 4 & 12.82 & 70.52 & LR \\
\hline 12 & 2580 & 8.86 & 8.60 & 9.29 & 18.25 & -0.2 & 13.6 & 4.35 & 4.2 & 12.47 & 34.77 & SR \\
\hline 13 & 1029 & 15.97 & 3.35 & 15.51 & 5.62 & 12.89 & 4.6 & 10.67 & 4.4 & 12.12 & 67.16 & MR \\
\hline 14 & 1752 & 11.77 & 13.68 & 5.69 & 27.02 & -7.16 & 16.2 & 2.58 & 4.2 & 12.47 & 25.36 & SR \\
\hline
\end{tabular}




\section{Conclusion}

Using of GIS and Water Quality Index (WQI) methods could provide precious and effective tool to can monitoring, summarize and report data to decision makers in order to help them to understand the quality of irrigation water within study area and have opportunity to reach to optimum using in the future. It could be concluded that, the descending order of water restriction use in the study area is SR > LR > MR > HR. Indeed, the (IWQI) reveals that, $27 \%$ of the region to be low restriction, $21 \%$ is moderate restriction, $14 \%$ is high restriction and around $38 \%$ is severe restriction for irrigation. This indicate that, more than half $(58 \%)$ of IWQI in the analysed surface water may avoided its use for irrigation under normal conditions. The low WQI values were particularly observed in the north east and south east where EC, SAR, $\mathrm{Na}^{+}$and $\mathrm{Cl}^{-}$concertation to be high in this direction. It is worth mentioning that, there is no order of water restriction in the study area. This research recommends that, precise measures and efficient methods to improve water quality must be implemented.

\section{REFERENCES}

Aliyu, T., O. Balogun, C. Namani, L. Olatinwo and A. Aliyu (2017). "Assessment of the presence of metals and quality of water used for irrigation in Kwara State, Nigeria". Pollution, 3(3): 461-470.

Ali, A. A. and F. S. Moghanm (2013). Variation of soil properties over the landforms around Idku Lake, Egypt. The Egyptian Journal of Remote Sensing and Space Sciences, 16(1): 91-101.

Almeida, C., S. Quintar, P. Gonzalez and M. Mallea (2008). Assessment of irrigation water quality. A proposal of a quality profile. Environmental
Monitoring and Assessment, 190 (6): 319.

APHA "American Public Health Association". (2012). Standard methods for examination of water and wastewater. $22^{\text {nd }}$ ed. AWWA and WEF, Washington USA.

Assar, W., A. Allam and A. Tawfik (2018). Assessment and data assimilation of agricultural drainage water for reuse in irrigation purposes. In Proceedings of the 2018 Advances in Science and Engineering Technology International Conferences (ASET), Abu Dhabi, United Arab Emirates, 6 Febuary-5 April; 1-5.

Ayers, R.S. and D.W. Westcot (1999). "The water quality in agriculture", 2nd. Campina Grande: UFPB. (Studies FAO Irrigation and drainage, 29).

Bernardo, S. (1995). "Manual of Irrigation". (4th ed), Vicosa: UFV, 488p.

Bhuyan, M., M. Bakar, A. S. M. Sharif, M. Hasan and M. Islam (2018). "Water quality assessment using water quality indicators and multivariate analyses of the old Brahmaputra River". Pollution, 4(3): 481-493.

Climatological Normal for Egypt (2011). "The Normal for Beheira Governorate from 1960 to 2011, Ministry of Civil Aviation, Meteorological Authority". Cairo, Egypt.

FAO (Food and Agriculture Organization) (1985). "Water Quality for Agriculture". FAO Irrigation and Drainage Paper No. 29. Rome, Italy, 174p.

Ghazaryan, K. and Y. Chen (2016). Hydrochemical assessment of surface water for irrigation purposes and its influence on soil salinity in Tikanlik oasis, China. Environmental Earth Sciences, 75(5): 383.

Hafez, A. (2005). Investigation of El-Salam Canal Project in Northern Sinai, Egypt. In Proceedings of the The 9th International Water Technology 
Radwa A. El Behairy, et al.,

Conference, IWTC9, Northern Sinai, Egypt, 1 Janaury; 953-970.

Holanda, J. S. and J. A. Amorim (1997). "Management and control salinity and irrigated agriculture water" In: Congresso Brasileiro de Engenharia setting, 26, Campina Grande, 137-169.

Huntington TG. 2006. Evidence for intensification of the global water cycle: review and synthesis. J. Hydrol. 319:83-95

Jafar Ahamed, A., K. Loganathan and S. Ananthakrishnan (2013). "A comparative evaluation of groundwater suitability for drinking and irrigation purposes in Pugalur area, Karur district, Tamilnadu, India". Arch. Appl. Sci. Res. 5: 213-223.

Jassim, S. Z. and J.C. Goff (2006). "Geology of Iraq", Pub., Doline, First edition, 341p.

Jerome, C. and A. Pius (2010). "Evaluation of water quality index and its impact on the quality of life in an industrial area in Bangalore, South India", American Journal of Scientific and Industrial Research, 13: 595-603.

Khalaf, R. M. and W. H. Hassan (2013). "Evaluation of irrigation water quality index IWQI for Al-Dammam confined aquifer in the west and southwest of Karbala city, Iraq", International Journal of Civil Engineering IJCE, 23: 21-34.

Khan, R.A., H. Juahir, M.K. Yusoff, S.M. Zain and T.I.T. Hanida (2012). Using Principal Component Scores and Artificial Neural Networks in Predicting Water Quality Index; INTECH Open Access Publisher: Rijeka, Croatia, 271: 283-300.

Khater Abd Elhamed., Yoshinobu Kitamura., Katsuyuki Shimizu., Hiroaki Somura and Waleed H. Abou EI Hassan (2014). "Improving water quality in the Nile Delta irrigation network by regulating reuse of agricultural drainage water". Journal of Food, Agriculture \& Environment, 12 (3\&4): 329-337.

Meireles, A., E. M. Andrade, L. Chaves, H. Frischkorn and L. A. Crisostomo (2010). "A new proposal of the classification of irrigation water", Revista Ciência Agronômica, 41, (3): 349-357.

Miller R.W. and D.T. Gardiner (2007). Soils in our environment $9^{\text {th }}$ edn., Prentice Hall-Inc, Upper Sddle River, New Jersey 07458, ISBN 0-13-020036-0 (2007) 452.

Mohammed, M.N. (2011). "Quality assessment of Tigris river by using water quality index for irrigation purpose", European Journal of Scientific Research, 57 (1):15-28.

Negm, A. M., E.E. Omran, M. A. Mahmoud and S. Abdel. Fattah (2019). Conventional water resources and agriculture in Egypt. Hdb Env Chem., 74: 659-682.

Noori, R., A. Karbassi, A. Khakpour, M. Shahbazbegian, H. M. K. Badam, and M. Vesali-Naseh (2012). Chemometric analysis of surface water quality data: Case study of the Gorganrud River Basin, Iran. Environmental Modeling and Assessment, 17(4): 411-420.

RASUL M. Khalaf and Waqed H. Hassan. (2013). EVALUATION OF IRRIGATION WATER QUALITY INDEX (IWQI) FOR ALDammam Confined Aquifer In The West AND SOUTHWESt OF Karbala City, IRAQ.International Journal of Civil Engineering (ljce) (3): 21-34.

Richards, L. A. (1954). "Diagnosis and Improvement of Saline and Alkali Soils", U. S. Department of Agriculture Handbook, Vol. 60, Washington D. C., USA. p.160.

Rokbani, M.K., N. Gueddari and R. Bouhlila (2011). "Use of Geographical Information System and Water Quality Index to Assess Groundwater Quality in El Khairat Deep Aquifer (Enfidha, Tunisian Sahel)", Iranica Journal of 
Energy and Environment, 2, No (2), 133-144.

Said, R. (1993). The River Nile Geology and Hydrology and Utilization. Pergmon Press, Oxford.

Salahat, M., M. Al-Qinna, K. Mashal and M. Hammouri (2014). Identifying major factors controlling groundwater quality in semiarid area using advanced statistical techniques. Water Resour. Manag., 28: 3829-3841.

Scofield, F.E. (1936). The salinity of irrigation water. Smith. Instit. Ann. Rep., 1935: 275-283.

Simsek, C. and O. Gunduz (2007). "IWQ index: A GIS integrated technique to assess irrigation water quality",
Environmental Monitoring and Assessment, 128: 277-300.

Stoner, J. D. (1978): Water-quality indices for specific water uses. Department of the Interior, Geological Survey.

UNESCO (UN Educ. Sci. Cult. Organ). (2009). The United Nations World Water Development. Report 3: Water in a Changing World. Paris/New York: UNESCO/Berghahn Books.

Venkateswaran, S., M. Vijay Prabhu, M. Mohammed Rafi and L.K. Vallel (2011). Assessment of groundwater quality for irrigational use in Cumbum Valley, Madurai District, Tamil Nadu, India. Nat. Environ. Pollut. Technol. 10: 207212. 
Radwa A. El Behairy, et al.,

تقييم ورسم الخرائط المكانية لموئثر جودة المياه السطحية للرى بمنطقة شمال

غرب دلتا التيل ، مصر

رضوه عبدالله البحيرى، أحمد عبدالفتاح البارودى، محمود محمد إبراهيم، محمد سليمان شكر

قسم الأراضى والمياه، كلية الزراعة، جامعة طنطا.

الملخص العربى

أصبح نقص المياه وتلوثها من أكثر المخاطر التي تواجه مصر في الوقت الحاضر . لذا فإن تقييم جودة المياه يعتبر

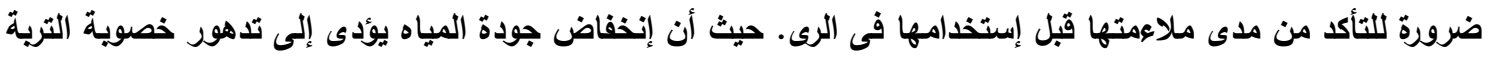

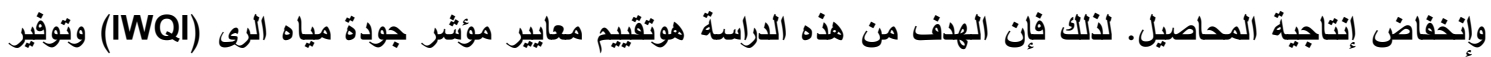

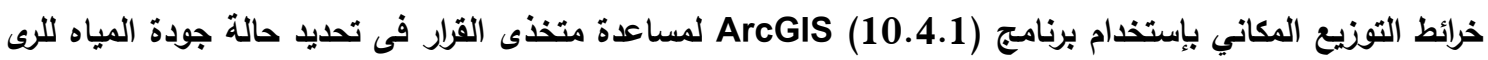

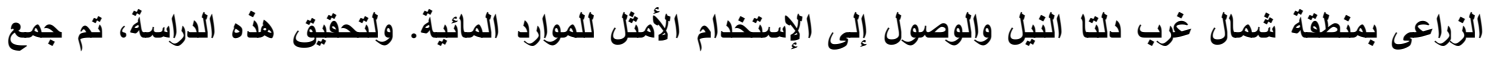
عينات المياه من 14 مصدر لمياه الرى السطحية داخل منطقة الدراسة خلال أكتوير 2019. وتم تقاير الخواص

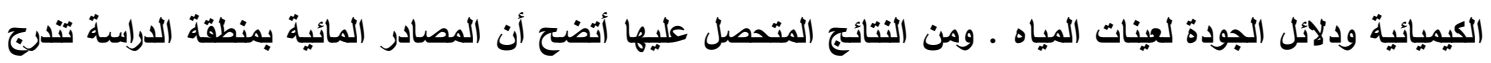

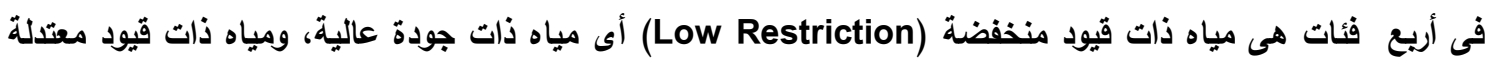
(High Restriction) أى مياه متوسطة الجودة، ومياه ذات قيود مرتفعة (Moderate Restriction)

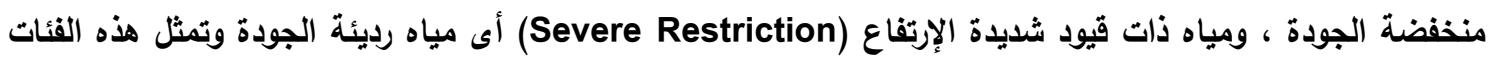
الأربعة مساحات قرها 178، 138، 92، 249 كيلو متر مريع على التوالي. وأظهرت خرائط التوزيع المكانى أن المياه

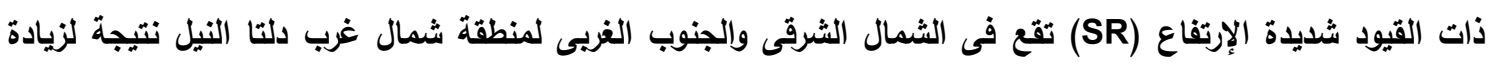
الملوحة (EC) و نسبة إدمصاص الصوديوم (SAR) وأيون الصوديوم الموجب (

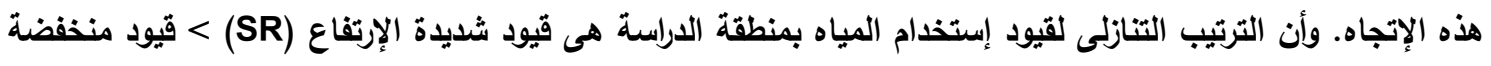

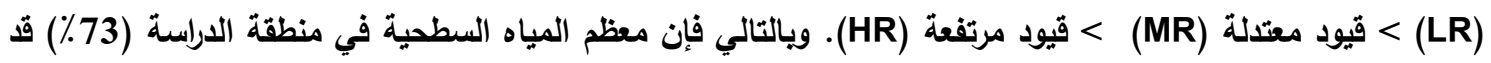

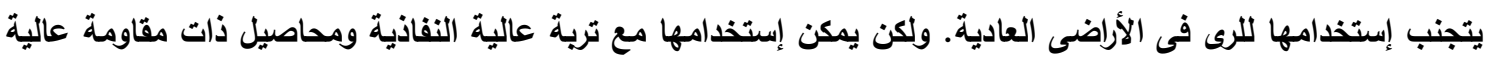
للملوحة مع إستخدام ممارسات خاصة للتحكم فى الملوحة.

أسماء السادة المحكمين

أ.د// عيسوى قاسم محمد رزق كلية الزراعة - جامعة طنطا

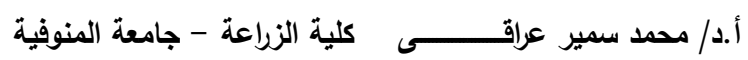

